\title{
DON COSSACKS AND THE BATTLE OF RASSEVAT ON SEPTEMBER 4, $1809^{1}$
}

\author{
Andrey V. Venkov \\ Federal Research Centre The Southern Scientific Centre of the Russian Academy of Sciences (SSC RAS), \\ Rostov-on-Don, Russian Federation
}

\begin{abstract}
Introduction. The Russian-Turkish war of 1806-1812 was the longest military conflict between Russia and Turkey. In the hope to force the Turks to peace, Russian troops crossed the Danube several times and fought for key fortresses on its banks. One of the battles on the right Bank of the Danube in 1809 was won practically by the Don Cossacks alone. In this battle Russian troops were led by such famous military leaders as Bagration, Miloradovich, Platov. After this battle Miloradovich and Platov were promoted to "full generals" (general in chief). Methods and materials. This battle is also interesting because the state archive of Rostov region has a very detailed collection of documents about it. Of all the documents relating to this war, the greatest number refers to the battle of September 4, 1809, because after it Don ataman Platov received his highest rank. The purpose of this study is to identify reasons for such an unusual victory. Analysis and results. The author investigates the course of the battle in detail using archival materials. The study shows that Russian forces were twice as superior to Turkish ones; during the battle, the command made a number of mistakes, which did not allow to completely surround the Turkish troops. High awards received by the command for this battle did not quite correspond to the level of success. The Russian commanders had friends at court and this partly affected the awards.

Key words: Cossacks, battle, Russian-Turkish war, awards, blockade, maneuver.

Citation. Venkov A.V. Don Cossacks and the Battle of Rassevat on September 4, 1809. Vestnik Volgogradskogo gosudarstvennogo universiteta. Seriya 4. Istoriya. Regionovedenie. Mezhdunarodnye otnosheniya [Science Journal of Volgograd State University. History. Area Studies. International Relations], 2020, vol. 25, no. 5, pp. 185-196. (in Russian). DOI: https://doi.org/10.15688/jvolsu4.2020.5.15

УДК 94(47).072.3

Дата поступления статьи: 01.04.2019

ББК 63.3

Дата принятия статьи: 28.05.2019
\end{abstract}

\section{ДОНСКИЕ КАЗАКИ И СРАЖЕНИЕ У РАССЕВАТА 4 СЕНТЯБРЯ 1809 ГОДА ${ }^{1}$}

\author{
Андрей Вадимович Венков \\ Федеральный исследовательский центр Южный научный центр РАН (ЮНЦ РАН), \\ г. Ростов-на-Дону, Российская Федерация
}

\begin{abstract}
Аннотация. Русско-турецкая война 1806-1812 гг. была самым продолжительным военным конфликтом между Россией и Турцией. Чтобы принудить турок к миру, русские войска несколько раз переходили Дунай и вели бои за ключевые крепости на его берегах. Одно из сражений на правом берегу Дуная в 1809 г. было выиграно практически одними донскими казаками. Русскими войсками в этом бою руководили такие известные военачальники, как Багратион, Милорадович, Платов, за что последние были произведены в «полныегенералы» (генерал-аншефы). Сражение у Рассевата интересно еще и тем, что в Государственном архиве Ростовской области есть достаточно подробная подборка документов о нем. Из всех материалов, касающихся ¿ данной войны, наибольшее их количество относится именно к сражению 4 сентября 1809 г., поскольку за него ণ ๓ं победы. В статье на основе архивных материалов детально изучен ход сражения. Исследование показало, что русские силы вдвое превосходили турецкие; в ходе сражения командование совершило ряд ошибок, не позво气 совсем соответствовали уровню успеха. Здесь сказались придворные связи русских командующих.

Ключевые слова: казаки, сражение, Русско-турецкая война, награды, окружение, маневр.
\end{abstract}


Цитирование. Венков А. В. Донские казаки и сражение у Рассевата 4 сентября 1809 года // Вестник Волгоградского государственного университета. Серия 4, История. Регионоведение. Международные отношения. -2020 . - Т. 25, № 5. - С. 185-196. - DOI: https://doi.org/10.15688/jvolsu4.2020.5.15

Введение. Как считали военные историки, Русско-турецкая война 1806-1812 гг. была самой продолжительной из всех войн, которые Россия вела против Турции [9, с. 238]. Одновременно в ходе этого затянувшегося конфликта Россия воевала с наполеоновской Францией, Швецией, Персией и даже Австрией.

Мы обратили внимание на сражение при Рассевате, потому что оно было выиграно в основном казаками, за что командир корпуса М.И. Платов получил чин генерала от кавалерии. Вместе с ним «полным генералом» стал еще один из героев тех войн - Милорадович. Примечательно, что именно по этому сражению в ГАРО (фонд 46 - Войсковой штаб Войска Донского) имеется впечатляющая подборка оригинальных документов, связанная, видимо, с указанным обстоятельством производства М.И. Платова в «полные генералы». Интересно и то, что данный бой был отражен в мемуарной литературе, и есть возможность сравнить, как события описывались одним и тем же лицом непосредственно в день боя (или через несколько дней) и через несколько десятилетий.

Цель данного исследования состоит в выявлении причин столь необычной победы, одержанной, как утверждали очевидцы, одной иррегулярной конницей, а кроме того - выяснить, почему победа, за которую два русских генерала получили предельно высокие для них чины, не привела к победоносному завершению войны. Для достижения этой цели мы ставим задачи: сравнить силы противоборствующих сторон; рассмотреть непосредственно ход сражения; выявить наиболее важные факторы победоносного исхода боя.

Методы и материалы. Данное историческое исследование опирается на большое количество работ по истории Русско-турецкой войны 1806-1812 гг., как дореволюционных, так и советского периода. Однако роль казаков в них специально не рассматривалась. Из последних исследований большой интерес вызывают диссертации: А.И. Сапожникова «Граф Матвей Иванович Платов: (Опыт научной биографии)» (1995 г.) [17] и С.Г. Вос- кобойникова «Участие донских казаков в русско-турецкой войне 1806-1812 гг.» (2006 г.) [3]. Однако работы, посвященной непосредственно сражению при Рассевате в 1809 г., нет.

В основу исследования легли воспоминания генералов Ланжерона, А.К. Денисова, опубликованные сборники документов и документы, хранящиеся в ГАРО.

Материалы изучались с опорой на принципы историзма и объективности, что является традиционным для исследований такого рода. Естественно, были применены специально-исторические методы: антропологический, проблемно-хронологический и сравнительноисторический

Анализ. В течение всего 1808 г. тянулось заключенное между Россией и Турцией перемирие. Александр I был недоволен его условиями. Благодаря окончанию войны с Францией он увеличил численность войск на турецком фронте до 80 тысяч человек. Вместе с новыми войсками на Дунай подошли несколько полков донских казаков во главе с М.И. Платовым. Генерал Ланжерон, участник той войны, вспоминал, что командующий армией фельдмаршал А.А. Прозоровский Платова любил и ему покровительствовал [13, с. 571]. Платов был назначен начальником авангарда армии, затем получил в свое командование отдельный корпус.

Тем временем в Турции произошел очередной государственный переворот, и новое правительство решило разорвать перемирие с Россией.

Чтобы заставить турок подписать выгодный для России мир, решено было перейти Дунай. Поэтому все силы сперва бросили на отвоевание Добруджи, территории между Дунаем и морем, а затем предполагали удар на Силистрию - ключевую турецкую крепость на Дунае. Опыт предыдущих войн показывал - впереди, при вступлении в Болгарию, армию ожидают трудности. В Болгарии начинались горы и леса, широкая река в тылу, трудности доставки припасов и оружия. Главным для русских войск на этом этапе стало взятие ключевой турецкой крепости Силистрии. По- 
том можно было идти на Варну и, взяв ее, получать припасы из России морем. Операция по форсированию Дуная была рискованной. Фридрих II еще во время предыдущей войны России с Турцией в 1768-1774 гг. рекомендовал - лучше преследовать разбитых турок на левом - валашском - берегу Дуная, а не переправляться за Дунай перед боеспособной армией $[18$, с. 59]. И главнокомандующий А.А. Прозоровский, поклонник Фридриха II, долго колебался, но все же переправил войска за Дунай в его нижнем течении. Здесь Прозоровский умер. Скончался в лагере за Дунаем у Мачина 9 августа 1809 года.

Командующим российской армией на Дунае был назначен генерал П.И. Багратион. 11 августа Багратион принял командование и, помня, что «минута драгоценна», продолжил операцию.

Генерал Ланжерон считал: «Новый план кампании был превосходно разработан, и все операции были ведены энергично и умно» [12, c. 683]. Багратион же писал 19 августа: «Я стараюсь отыскать общий план военных операций покойного главнокомандующего на нынешнюю кампанию, но в бумагах его я ничего не нашел... Таким образом, общий план его мне вовсе неизвестен» [1, с. 368-369]. Так что «энергично и умно» Багратион, видимо, действовал по наитию.

В течение короткого времени русские войска заняли территорию Северной Добруджи, заняли или осадили крепости Мачин, Гирсово, Кюстенджи, что привело к определенному распылению войск. 30 августа корпус Милорадовича, двигавшийся вверх по правому берегу Дуная, вышел к селению Черноводы и обнаружил впереди в селении Рассеват турецкие войска, прикрывавшие дорогу на Силистрию. Главнокомандующий генерал Багратион принял решение собрать часть своих войск в кулак при Черноводах и атаковать турок в Рассевате.

Милорадович подошел к Черноводам и развернул свои войска незаметно для турок. 30 августа произошел кавалерийский бой, в котором участвовали до тысячи турецких всадников и два казачьих полка из корпуса Милорадовича под командованием генерала П. Иловайского. Тем не менее расположение самого русского корпуса турками раскрыто не было.
1 сентября к войскам Милорадовича подошел казачий отряд генерала А.К. Денисова 6-го из корпуса М.И. Платова и «донес обо всем нужном, равно и о том повелении от атамана Платова - чтобы не соединяться с его корпусом, а быть несколько отдельно от оного» $[5$, с. 175$]$.

В тот же вечер казаки Денисова 6-го и Иловайского «с час времени» вели перестрелку с турками, после чего противники разошлись по своим лагерям.

Силы противника выяснены не были, но казаки знали «по прежним донесениям и показаниям пленных, что в сих местах находился один паша, имеющий от 4-х до 5-ти тысяч войска» $[5$, с. 176].

После этого, как вспоминал Ланжерон, Милорадович «возымел желание немедленно атаковать, со своими 4.000 чел., Хозрефа-пашу. Желание это было в высшей степени неосторожным, но он никогда ни в чем не сомневался, в особенности после того, как ему один раз посчастливилось разбить сераскира, который был гораздо слабее, чем его считали... Багратион не только запретил ему предпринять такое рискованное движение, но и вообще предпринимать что-либо без его разрешения» [12, с. 691]. Однако, поскольку между Багратионом и Милорадовичем еще со времен Итальянского похода Суворова шло негласное соревнование (и Багратион стал опережать), главнокомандующий, не в шутку встревоженный, поспешил к месту развивающихся событий. С собой Багратион взял лишь корпус М.И. Платова.

100 верст от Кюстенджи войска Багратиона прошли по 30-градусной жаре [15, с. 212] и 2 сентября в Черноводах соединились с войсками Милорадовича.

Разведка доносила, что у турецкого командующего Хозрефа 15 тысяч войска. Поэтому, прибыв 31 августа в Корасан, Багратион приказал графу П. Строганову, командовавшему платовским авангардом, разведать расположение турок. Граф Строганов перешел Троянов Вал, установил, что турки точно стоят в Рассевате, но количество их невелико, до 15 тысяч не дотягивает.

Багратион решил, что войск Милорадовича и Платова достаточно, чтобы разбить турок, и не стал привлекать дополнительные силы [12, с. 691$]$. 
Меж собравшимися у Черновод генералами, как уже указывалось, существовали сложные взаимоотношения.

Генерал Ланжерон, французский эмигрант, человек не чуждый литературному творчеству, прекрасный инженер, оставил воспоминания об этой войне и о героях ее. Будучи человеком нелицеприятным, он часто подмечал слабости своих сослуживцев. Из его мемуаров можно почерпнуть информацию об отношениях меж указанными нами героями. Много места там уделено казакам, особенно последовавшему производству Платова в «полные генералы»: «Платов, будучи старше Милорадовича, был мало польщен своим возвышением, он хорошо понимал, что эта милость должна больше радовать самого Багратиона, который возвел его в этот чин. Несмотря на то что он был генерал-лейтенантом моложе меня и многих других генералов, прослуживших с большей пользой, чем он, никто не был шокирован, увидав Платова генеральным гетманом всех казаков, имея всего 60 лет от роду. Он был уже генерал-майором, когда мы были только полковниками, и потерял свое старшинство при Павле I, который держал его в продолжение трех лет в строгом тюремном заключении или в суровой ссылке... Благодаря его службе, совершенно изолированной от регулярной, он редко имел сношения с нами, что и было причиной его неспособности, хорошо всем известной, командовать корпусами или армиями, составленными из регулярных войск, но, тем не менее, обстоятельства эти не возбуждали ни боязни, ни зависти со стороны его сослуживцев» $[12$, с. 696]. То есть, по мнению Ланжерона, Платов свой чин получил заслуженно, но командовать корпусом или армией был не способен.

В целом же Платов Ланжерону не понравился. Отдавая Платову должное, что тот всегда был своего рода эталоном казака в армии, Ланжерон указывал на платовский возраст, якобы тому было уже под 60 лет (в действительности - 57) и поэтому он уже не имел прежней энергии. Еще Ланжерону казалось, будто казаки не любят Платова за то, что он в свое время считался любимцем Потемкина, да и в описываемый период был моден при дворе. Но особенно автор мемуаров подчер- кивал, что Платов относился к регулярным войскам с глубочайшим презрением.

Платову Ланжерон противопоставлял командовавшего авангардом Милорадовича генерала П.В. Иловайского 2-го, который, по мнению Ланжерона, был не только храбрец, но и очень опытный генерал, способный командовать отдельным корпусом. Позже, в 1810 г., Иловайский погиб, и Ланжерон, описывая смерть генерала, охарактеризовал его так: «Он обладал красивой наружностью и благородной осанкой; сидя на великолепном белом коне, таком же гордом и величественном, как его всадник, герой мчался впереди своих подчиненных, внушая к себе уверенность и уважение всей армии... Россия в его лице лишилась прекрасного генерала. Тем не менее, среди казаков он не пользовался любовью, так как был слишком европеец для них; он говорил по-французски, читал хорошие военные книги и любил регулярные войска» $[14$, c. 169,173$]$.

Таким образом, Ланжерону был неприятен М.И. Платов, который, в свою очередь, не любил и презирал регулярные войска, но очень нравился П.В. Иловайский, оказывающий регулярным войскам всякие почести. Впрочем, по мнению Ланжерона, простые казаки не питали любви ни к Платову, ни к Иловайскому.

Кроме того, Ланжерон отмечал: «Багратион, чувствуя себя смущенным, опередив по службе Платова (Платов был уже генералмайором, когда кн. Багратион был только произведен в офицеры), не сумел поставить себя по отношению к нему» $[12$, с. 684$]$.

Действительно, переписка Багратиона и Платова «пропитана» доверительностью и некой совещательностью. В письме Багратиона М.И. Платову из лагеря «при устье Мачинского гирла» от 16 августа 1809 г. автор жалуется своему адресату на покойного фельдмаршала («и вам вязал руки, и армию разбросал так, что нигде нет в куче нанести неприятелю удар»), на инженерную часть («Вышло, что по части инженерной ни фашин, ни пионеров нет налицо. Я должен беситься и целый день сим заниматься») и далеко не в уставных выражениях говорит о будущих совместных действиях («И совокупно могу сойтись с вами, тогда вы подвинетесь к Троянс- 
кому валу; и буде до того Гирсов не отдастся, я им займусь, или какие обстоятельства случатся, мы с вами так и поступим» [6, с. 355].

Непростыми были отношения и между казачьими генералами. Притчей во языцех на Дону стало противостояние между М.И. Платовым, представителем «черкасни» - жителей донской казачьей столицы, и А.К. Денисовым, представителем влиятельного провинциального «пятиизбянского» рода (казаки Денисовы, происходившие из станицы Пятиизбянской, во 2-й половине XVIII в. активно боролись за влияние на Войско; генерал Ф.П. Денисов стал первым графом из донских казаков). Эти взаимоотношения проявились и в ходе сражения.

1 сентября примчавшийся к месту боя князь Багратион сам произвел разведку местности и обнаружил, что «Рассовать это большая деревня, расположенная в 5 верстах от Троянова Вала, на склоне двух гор, разделенных оврагом. Возвышенности эти господствуют над деревней и рекой, вдоль которой, на протяжении 2 верст, тянется узкая дорога в Силистрию. Далее, дорога эта проходит мимо озера и пересекает сильно болотистый ручей, через который был перекинут очень плохой мост... На горе и в долине турки возвели ретраншементы, которые не имели между собой связи и были открыты с флангов... Позиция турок была очень неудачна, она не имела ни обстрела, ни удобного пути отступления» [12, с. 692].

Проведя рекогносцировку, Багратион написал диспозицию: корпусу Милорадовича атаковать Рассеват в лоб, а корпусу Платова обойти турок и отрезать им дорогу отступления на Силистрию. Оба корпуса имели под ружьем не более 12000 человек.

Вызывает удивление тот факт, что турки, имея всего 7000 вооруженных солдат и жителей и 14 орудий, не наступали и не отступали. Они словно ожидали, когда русские придут и их разобьют. Как показали последующие события, они даже не охранялись. Командовали ими, судя из русского приказа о награждениях, сераскир Хозрев-Мегмет-паша и аяны Илин-оглу, Яур Гасан и Тулум-оглу [11, с. 72].

Ланжерон удивлялся беспечности турецкого командования: «Если бы Хозрев имел на Трояновом Валу хоть только 2 пикета, выс- тавленных в 6-7 верстах от его лагеря, то он мог быть своевременно уведомлен о движении и силах Багратиона, так как с валов видна была местность на протяжении 50 верст. Воистину можно сказать, что военачальник, ведущий войну против турок, часто может приобрести славу и честь дешевым способом» [12, c. 693].

Русские войска выступили в полдень 3 сентября из Черноводов. Корпус Милорадовича прошел дефиле, отделяющее Троянов Вал от Черноводов, и сделал привал на берегу Дуная, казаки, входившие в этот корпус, остались позади, на валу. Платов наступал левее Милорадовича, он тоже сделал привал, но позади вала. Пока войска отдыхали, была установлена связь корпусов Платова и Милорадовича. Далее войска двинулись с прежней осторожностью. Турецких передовых постов они не встретили. Милорадович шел справа, Платов - слева, его авангард пошел отрезать туркам путь отступления [15, с. 202].

В 3 часа утра 4 сентября наступление началось. Милорадович наступал, выстроив войска в две линии пехоты и кавалерии. Первой линией командовал граф Цукато, второй - полковник Уманец. Павел Иловайский шел впереди с авангардом (полки Иловайского 2-го и Иловайского 11-го).

Корпус Платова наступал пятью колоннами. В составе корпуса числились полки: Атаманский, Барабанщикова 2-го, Денисова 6-го, Ефремова 3-го, Иловайского 5-го, Иловайского 10-го, Кутейникова 2-го, Сысоева 3-го, 1-я и 2-я Донские конно-артиллерийские роты. В диспозиции значилось: «Корпус генерал-лейтенанта Платова сентября 4 дня пополуночи в начале 2-го часа выступает для атаки неприятеля следующим порядком»: впереди шли платовские казаки (Ланжерон написал - «массы казаков»). Граф Павел Строганов командовал этим казачьим авангардом (полками Атаманским, Кутейникова 2-го, Ефремова 3-го и Барабанщикова 2-го). Затем шли 3 егерских батальона с 6 орудиями Донской конной артиллерии и Чугуевский уланский полк, этой колонной командовал генерал-майор князь Трубецкой. За ними шла колонна князя Репнинского - Новгородский и Украинский мушкетерские полки и 6 орудий. Далее с драгунами (Дерптский и Стародубовский полки) и с 6 донскими конными ору- 
диями шел граф фон дер Пален. Замыкала движение колонна генерал-майора Бахметьева Архангелогородский и Воронежский мушкетерские полки и 6 орудий. Предполагалось, что, «когда приказано будет», пехотные колонны развернутся в три каре [4, л. 1]. Особняком двигался еще один казачий отряд: «Бригады генерал-майоров Денисова 6-го, Иловайского 5-го, дабы пресечь неприятеля в случае [его] ретирады к Силистрии, следуют слева по особой дороге» [4, л. 1 об., 11]. Таким образом, Денисов 6-й и Иловайский 5-й с четырьмя полками казаков (полки Денисова 6-го, Иловайского 5-го, Иловайского 10-го, Сысоева 3-го) составляли как бы шестую колонну, двигавшуюся левее корпуса Платова с целью отрезать турок от Силистрии.

Сам Денисов в своих мемуарах отрицает, что имел такое задание: «Я явился в команду войскового атамана, Платова, который приказал мне следовать отдельно, на небольшую дистанцию, с левого флангу» [5, с. 177]. Во время движения присланный от Платова князь Мадатов указал Денисову место, где остановиться: «...Место, более возвышенное, но кустарниками не заросшее и на которое, по крутости онаго, с трудом казаки могли въезжать. Я видел, что и сие место весьма неудобное, но повиновался начальнику моему, взошел и остановился в боевом порядке. Атаман потребовал от меня Сысоев полк, тогда я остался с тремя полками и получил словесное приказание от атамана, а после и прямо от главнокомандующего, чтобы наблюдал слева, куда мною и были уже две партии посланы, да и сам я с занятого мною высокого места на большую дистанцию мог все видеть» [5, с. 178]. Таким образом, А.К. Денисову оставили три полка и поручили не обходить турок, а наблюдать влево - прикрывать операцию слева. «Вторично войсковой атаман мне приказал - наблюдать движение его бунчуга, и тогда, когда я увижу его в движении, то, по направлению онаго, спешил бы с полками на неприятеля» [5, с. 178]. То есть Платов взмахами бунчука, конского хвоста на древке, указывал Денисову направление движения непосредственно в ходе боя.

Прежде чем достигнуть Рассеватских возвышенностей, корпусу Платова пришлось в темноте перейти ряд оврагов. Конница, освещая дорогу, выдвинулась влево (Чугуевский уланский полк, которым командовал Лисаневич) и вправо (драгуны графа Павла фон дер Палена).

Планировалось, что, выйдя на место, казачий авангард сместится на крайний правый фланг. Егеря составят центральное каре и станут острием клина, за ними построятся драгуны. Слева и справа уступом за егерским каре станут в такие же каре колонны Репнинского и Бахметьева. Чугуевские уланы должны были составить оконечность левого фланга [4, л. 2].

Вплотную подойти к лагерю все же не удалось. Из рапорта графа Строганова явствует, что казаки авангарда «заняли на рассвете высоты, окружающие Розовато, и открыли неприятеля в большом количестве» [4, л. 23]. Сражение началось в 6 часов утра. Открыла его турецкая конница, вышедшая из лагеря. Турки атаковали передовых казаков Платова. Более того, в 1,5 верстах от лагеря в глубоком овраге часть турецкой конницы, выступившая заранее, успела стать скрытно. Этот отряд предназначался для удара русским во фланг и в тыл, когда они минуют овраг.

Из рапорта Кутейникова 2-го следует, что он с тремя полками столкнулся с неприятелем и «удерживал оного произвождением с ним сильной перестрелки» [4, л. 25].

Платов, следовавший впереди своего корпуса, построил боевой порядок, даже спешил часть казаков. Граф Цукато, пройдя с первой линией Милорадовича возвышенности, сомкнулся с Платовым флангами и выслал на поддержку спешенным казакам стрелков 6-го егерского полка. Эти части выдавили турок с высот и заставили отступить в лагерь. Вторая линия корпуса Милорадовича достигла того самого глубокого оврага, где пряталась турецкая конница.

Милорадович развернул против конных турок Сибирский гренадерский полк и белорусских гусар и, считая свой правый фланг и тыл достаточно прикрытыми, не останавливаясь повел остальные войска на деревню Рассеват. Заняв возвышенности, он открыл артиллерийский огонь, который скоро заставил турецкую артиллерию замолчать.

Дело на правом фланге решилось одной конницей. А.И. Михайловский-Данилевский писал, что турки вышли из города толпами и 
напали на Милорадовича, который «прогнал их казаками» [15, с. 202].

Здесь отличился Иловайский 12-й, который, «начальствуя охотниками из казаков, на правом нашем крыле, атаковал ими появившуюся из окрестностей конную толпу турков, отбросил ее, врезался в пехоту, выгнал ее из окопов и взял пушку. Вслед за тем, произведя еще одну атаку на собравшуюся пехоту и конницу, Иловайский разбил их и овладел двумя орудиями» [10, с. 61].

В то же самое время подошли пехотные колонны Платова и открыли сильную канонаду. Репнинский повел свой Новгородский полк влево, «чтобы, - как считал Ланжерон, - дождаться ген. Денисьева, удалившегося еще более влево со своими казаками» [12, с. 693], а генерал Бахметьев со своими полками, наоборот, стал сдвигаться правее, в сторону корпуса Милорадовича. Видимо, русские генералы старались создать единую боевую линию от войск Милорадовича до отряда Денисова 6-го. Русская артиллерия, выбив огнем турок с их позиций, заняла их сама и начала обстреливать деревню.

Выставленные русскими батареи «действовали не более получаса» [15, с. 203]. Турки заколебались. Платов подал сигнал к общей атаке. Генерал-майоры Кутейников и Строганов с казаками корпусного авангарда бросились в атаку и опрокинули турок [7, с. 102].

Мы помним, что Денисов 6-й должен был следить за движением платовского бунчука, и генерал-майор Лисаневич, командир чугуевских улан, рапортовал: «И по выставленному у господина генерал-лейтенанта и кавалера Платова знамю по приказанию Вашего сиятельства повел полк в атаку...» [4, л. 15].

Согласно рапорту Кутейникова 2-го, он дождался, когда Платов подвел и устроил свой корпус, а затем ударил со своей бригадой туркам в центр их построения и во фланг [4, л. 25]. Судя по рапорту Ефремова 3-го, в центр ударил его полк [4, л. 26]. Кутейников и Барабанщиков ударили по флангам. Несмотря на сильное сопротивление, турок опрокинули, гнали до речки и загнали в эту речку. Полк Барабанщикова 2-го первым прорвался на мост и выскочил на другой берег [4, л. 27]. Другие полки бригады Кутейникова преследовали бегуще- го через речку неприятеля вброд - «переправились по следам его» [4, л. 25 об.].

Атаманский полк, стоявший левее бригады Кутейникова, произвел «на неприятельскую конницу сильный удар в дротики, опрокинул и гнал по возвышенности». Через речку он переправился в трех верстах от моста [4, л. 24].

Каре Репнинского, которое двигалось в сторону отряда Денисова, столкнулось с турецким отрядом, который, как показалось Репнинскому, стал обходить его левый фланг. Командир Украинского полка Кушников занял господствующую высоту и установил там батарею. «Неприятель, бывши поражен во всех пунктах легкою кавалериею, устрашился также сим быстрым движением пехоты», - рапортовал генералмайор Репнинский [4, л. 6-6 об.].

Действительно, турки были «поражены во всех пунктах» легкой кавалерией - казаками. Командир Дерптского драгунского полка фон дер Пален рапортовал, что получил приказ «подкрепить казачьи полки» уже после того, как турецкие конница и пехота, «скопясь в одну толпу, начали ретироваться по горе к стороне Силистрии» [4, л. 16].

Турки бросились уходить по двум дорогам, на Силистрию и Кузгун. Турецкая конница уходила по Силистрийской дороге. Пешие турки отступали вдоль Дуная. К 9 часам утра сражение было выиграно.

«Турки бежали со всех сторон по дороге в Силистрию, бросив свои ретраншементы и орудия, - вспоминал Ланжерон. - Если бы ген. Денисьев отошел еще левее, и Платов, отрядив два каре для поддержки его, послал бы их занять дефиле, находящееся позади турецкого лагеря, то ни один бы турок не спасся, а если бы Емин-оглы, который участвовал в деле, был бы взят, то Силистрия осталась бы без защитников» [12, с. 694]. Но маневр не был совершен - возможность упущена.

Естественно, вопросы вызывают действия А.К. Денисова 6-го. Согласно рапорту Денисова 6-го, он дождался удара по туркам русского правого фланга и сам перешел в наступление. «Я пустил вперед из полков охотников на лучших лошадях при офицерах - [полка] имени моего есаул Болдырев, [полка] Иловайского 5-го - капитан Мельников, - и вслед за оными командировал подполковника Иловайского 10-го с полком его имени» [4, л. 17]. 
Турки, стоявшие против Денисова, были опрокинуты и побежали. Сам Денисов 6-й и Иловайский 5-й «с остальными казаками, составя лаву, гнались, чем наносили неприятелю страх; при первом же от Ризовато болоте принял я в команду 4 эскадрона Чугуевского уланского полка...» [4, л. 17].

В своих мемуарах Денисов 6-й рисует более сложную картину: «Армия наша была вблизи от меня и в виду моем; началась атака пальбою из пушек. При сем случае турки, видя, что я на высоте и не имею удобности скоро сойти с оной и им вредить, стали - конные и пешие - сближаться к моим полкам, открыли стрельбу из ружей и ранили более 10-ти казаков, из которых некоторые от тяжелых ран скоро и померли. Наша армия пошла вперед, на неприятеля, и турки, не дожидаясь приближения оной, побежали: вся пехота вверх по Дунаю, по самому берегу, а конница - по разным направлениям. Тогда я, хотя и не мог видеть атаманского бунчуга, пустился с горы, но, по крутизне оной, с большим затруднением, так что казаки большею частию принуждены были сойти с лошадей и пешие спускались. Тогда предстояла мне другая гора, на которую не только невозможно было поспешно въезжать, но лошади с большим затруднением и шагом всходили. Взойдя на гору, я увидел, что неприятель опередил мои полки и многие казаки врассыпную преследуют онаго. Тогда я приказал и полковнику Осипу Иловайскому также врассыпную преследовать неприятеля, а сам, с моим полком и с полком генерал-майора Николая Иловайского, спешил догнать неприятельскую пехоту, заскакал ей наперед, но, по неудобности местоположения, не мог оной атаковать ни с флангов, ни с тылу, а спереду без артиллерии не мог остановить, о чем и донес тотчас атаману Платову и предлагал, что ежели угодно принудить сию турецкую пехоту к сдаче или побить, то чтобы прислал две пушки и несколько драгун, а сам я продолжал идти во фланг турок и не отставал от них; тут еще ко мне присоединились, при одном штаб-офицере, два или четыре эскадрона (хорошо не припомню) Чугуевских казаков» [5, с. 178]. Таким образом, Денисов 6-й не успел перехватить бегущую турецкую конницу, разминулся с ней, но пытался перехватить пехоту.
Согласно рапорту князя Трубецкого, он действительно послал прикрывавший его каре Чугуевский полк на помощь казакам [4, л. 13], а командир Чугуевского полка Лисаневич подтверждает, что 4 эскадрона командирского батальона полка направил в распоряжение Денисова. Согласно рапорту самого Денисова, сначала он пытался остановить уходящую вдоль Дуная меж болот турецкую пехоту «заезжал им вперед, производил стрельбу» [4, л. 17]. Потом, когда к указанным болотам подошел Иловайский 2-й из отряда Милорадовича, а к Денисову подошли чугуевцы, он со своими казаками и чугуевскими уланами «составил линию перед болотом» [4, л. 17 об.], то есть перекрыл туркам дорогу. Центр событий переместился к Дунаю. Как рапортовал Денисов, турецкая «конница, вышедшая на высоты, была почти вся истреблена, пехота же продолжала держаться берега» [4, л. 17 об.].

Участь турецкой конницы и впрямь была незавидной. «Казаки, гусары и драгуны вскоре настигли неприятеля и довершили поражение его», - писал Михайловский-Данилевский [15, с. 204]. «Вскоре» означало, что Милорадович и Платов преследовали турок конницей до 5 часов пополудни 20 верст. Сам Милорадович сражение под Рассеватом назвал в насмешку «охотой с борзыми».

«Преследование турок породило какойто спорт, где каждый, имевший лучшую лошадь, гнался в одиночку и рубил своего врага. Такая охота длилась до вечера, на протяжении 20 верст, когда лошади не в состоянии были двигаться дальше. В конце дня произошел довольно курьезный эпизод. Со склона довольно крутого холма было видно, как турки слезли с измученных лошадей и тащили их под уздцы, уходя от наших казаков, которые, в свою очередь, сделали то же и преследовали их таким же образом» [12, с. 695]. В Чугуевском уланском полку (в тех эскадронах, что не были командированы к Денисову) во время преследования «на скаку» пало 4 лошади [4, л. 21]. В полку Кутейникова 2-го казаки «от чрезвычайной скачки» бросили 12 лошадей запалили [4, л. 30].

Затем преследовали казаки графа Строганова и Иловайского 11-го. Строганов докладывал, что гнал турок не 20, а 30 верст [4, л. 23]. То же самое доложил командующий 
Атаманским полком Балабин [4, л. 24]. Ефремов 3-й версты не считал, доложил, что преследовали, «доколь совершенно казачьи лошади пришли в усталость» [4, л. 26]. Кутейников 2-й рапортовал, что паша едва спасся на переменных лошадях, почти все турецкие знамена были отбиты [4, л. 30]. Строганов дошел до Силистрии, вместе с ним на 7 верст к Силистрии подходили чугуевские уланы (шефский батальон) [4, л. 21]. Иловайский вышел к Кузгуну, появился под городом на рассвете 5-го, турки разбежались, в городе было взято 4 орудия и 13 зарядных ящиков.

Другие источники указывают, что эти подвиги совершил Иловайский 12-й: «По окончании сражения, когда разбитые турки спасались бегством по лесам и болотам, он преследовал их 30 верст и возвратился к армии с пленными и пятью отбитыми знаменами. На другой день он обратился за бежавшими к Кузгуну и захватил еще 4 орудия, 13 зарядных ящиков и запасы хлеба. Сии подвиги были награждены орденом Св. Анны 2 класса» [10, c. 61]. Согласно послужным спискам, под Кузгуном были казаки трех полков - Ефремова 3-го, Иловайского 2-го и Иловайского 11-го.

Турецкий лагерь был занят пехотой, первым в ретраншемент вошел князь Трубецкой с 7-м егерским полком. Трубецкой доносил, что полк вошел в город двумя колоннами во главе с полковниками Паскевичем и Лаптевым и в городе проявил «бескорыстие» $[4$, л. 13 об.], то есть не грабил. Архангелогородский полк был послан ловить турок, прятавшихся в дунайских камышах, и захватить лодки, на которых турки могли бы перебраться на другую сторону реки.

Попытки спастись в лодках действительно были, но донская казачья артиллерия пресекла все эти попытки, разбив точными выстрелами 4 лодки. Тех турок, которые пытались спастись вплавь, преследовали казаки Атаманского полка и полка Иловайского 11-го.

А.И. Михайловский-Данилевский подтвердил: «Охотники Атаманского и Иловайского 11-го полков переплыли на лошадях через Дунай и перекололи много турков» [15, с. 204].

Это событие вошло в учебное пособие для казачьих детей. Описывалось, как турки на парусных лодках бежали на ту сторону Дуная, а сотник Яновский на лошадях пресле- довал их вплавь. Турок догнали, перекололи, захватили лодки и на них вернулись обратно $[8$, c. 254].

Со своей стороны полковник Карпов 2-й представил к награде двух есаулов (Золотарева 7-го и Стрюкова 2-го), сотника (Кирпичева 2-го) и четверых урядников (Михаила Богатырева, Даниила Кирпичева, Петра Волошиневского и Якова Тарчукова) своей Донской конно-артиллерийской роты, которые огнем потопили турецкие лодки [4, л. 31].

Часть беглецов пыталась спрятаться в топях на правом берегу Дуная. Их ловили по болотам и камышам до вечера. Казаки и егеря перебили здесь множество турок и 150 взяли в плен.

Большая часть трофеев тоже была взята казаками. Из рапортов участников видно, что сам подполковник Сысоев 3-й захватил белое знамя (белое знамя считалось личным знаменем командующего) и отвез его Платову.

В сражении турки потеряли 30 знамен (из них 1 сераскера), 14 орудий, русскими взято 1000 пленных, в том числе 48 офицеров. Из 1000 пленных примерно 400 умерло в тот же вечер от ран. Убитых турок сначала не посчитали. Впоследствии доносили, что турок погибло от 2500 до 3000 человек.

Генерал Ланжерон в своих мемуарах детально указал потери русских войск: «Наша потеря заключалась: убитыми 7 казачьих офицеров, в числе их подполковник Ефремов, и 50 казаков. Ранено 20 офицеров и 150 казаков. Пехота не имела никаких потерь и не дала более 100 оружейных залпов» $[12$, c. $695-696]$.

А.К. Денисов 6-й в своих мемуарах писал: «На другой день узнал я, что атаман Платов в том, что мало неприятелей побито и взято в плен, винит меня и очень недоволен. Я нарочито был у главнокомандующего, чтобы раскрыть, в чем меня винят, и объяснить ему нужное в оправдание свое. Он в одобрение мне ничего не сказал, но весьма милостиво принял» [5, с. 179-180]. Действительно, главнокомандующий князь Багратион вряд ли считал это сражение судьбоносным, чтобы из-за него начинать расследование - кто и почему упустил турок.

Свою оценку сражению дал генерал Ланжерон: «На самом деле, это была про- 


\section{ИСТОРИЯ И КУЛЬТУРА НАРОДОВ ЮГА РОССИИ}

стая стычка, но наделавшая столько шуму в Петербурге, что было даровано столько же наград и даже более значительных, чем за кампанию 1807 и 1808 гг. против Наполеона» [12, с. 696].

Видимо, такая реакция в Петербурге объясняется связями героев баталии в придворных кругах, увлечением Багратиона Великой Княжной Екатериной Павловной. «Чтобы положить ему конец, Вел. княжну в апр. 1809 г. выдали замуж за принца Георга Ольденбургского. Но так как Б. не хотел примириться с этим фактом, то его произвели в генералы от инфантерии и направили в Молдавию. Прибыв сюда, Б. повел военные действия с обычною своею суворовскою быстротою и решительностью» [2, с. 330].

Князь Багратион был награжден орденом Святого Андрея Первозванного и получил 50 тысяч рублей [15, с. 205], генерал-лейтенанты Платов и Милорадович за это сражение были произведены в генерал-аншефы. Платов стал генералом от кавалерии, Милорадович - генералом от инфантерии.

Описывая подвиги Платова, Багратион не скупился на похвалы. Он писал, что Платов «украсил седую главу свою венцом славы, везде был впереди... пылая неограниченным рвением в исполнении предлежащей ему цели, сам с легким войском преследовал неприятеля» $[1$, с. 373$]$. Впрочем, вряд ли единственной причиной выдвижения М.И. Платова был рапорт Багратиона. Известно, что М.И. Платов долгие годы состоял в теплой дружеской переписке с Великой Княгиней Марией Федоровной, матерью Александра I, вдовой императора Павла [16].

Рядовые, участвовавшие в сражении, получили по 1 рублю [15, с. 205].

В дополнение к ордену Багратион получил право заключить мир с границей по Дунаю и требовать 20 миллионов пиастров за военные издержки.

Впоследствии были обвинения, что туркам дали бежать, эти беглецы усилили гарнизон Силистрии - и взять город русским войскам не удалось. В итоге перед приближением зимы русские войска вынуждены были вернуться за Дунай, что, по мнению очевидцев событий, продлило войну еще на несколько лет.

\section{Результаты:}

1. Имея превосходство в силах и небрежного, плохо охраняющегося противника, русские командиры упустили возможность «плотно» окружить врага более глубоким обходом пехоты, перекрыть ему путь отступления на Силистрию. Перекрыть и удерживать дорогу одной конницей довольно трудно.

2. В отсутствии указанного маневра, видимо, проявилось пренебрежительное отношение к пехоте, присущее М.И. Платову.

3. Полученные русскими командующими войсками награды и производства не соответствовали уровню военного успеха и были обусловлены, скорее, придворными связями.

4. Сражение показало превосходство казачьей конницы над турецкой кавалерией.

\section{ПРИМЕЧАНИЕ}

1 Работа выполнена в рамках реализации государственного задания ЮНЦ РАН на 2020 год (проект № 0256-2014-0012, № госрегистрации 01211354248).

The reported study was carried out as part of the implementation of the state task of The Southern Scientific Centre of the Russian Academy of Sciences (SSC RAS) for 2020 (project no. 0256-2014-0012, state registration no. 01211354248).

\section{СПИСОК ЛИТЕРАТУРЫ}

1. Анисимов, Е. В. Генерал Багратион. Жизнь и война / Е. В. Анисимов. - М. : Молодая гвардия, 2009. -832 c.

2. Военная энциклопедия : в 18 т. / под ред. полк. В. Ф. Новицкого и др. - Т. 4 : [Б - Бомба]. СПб. : Т-во И. Сытина, 1911, [обл. 1910]. -319-640, 5 с. : ил., карт.; 43 л. ил., карт.

3. Воскобойников, С. Г. Участие донских казаков в русско-турецкой войне 1806-1812 гг. : дис. ... канд. ист. наук : 07.00.02 / Воскобойников Сергей Георгиевич. - Ростов н/Д, 2006. - 265 с.

4. Дело о разгроме турецкого корпуса 4 сентября 1809 г. при укреплении Рассевато // Государственный архив Ростовской области (ГАРО). Ф. 46. - Оп. 1. - Д. 109. - 39 л.

5. Денисов, А. К. Записки донского атамана / А. К. Денисов. - СПб. : ВИРД, 1999. - 256 с.

6. Донская казачья энциклопедия Владимира Сидорова. - Т. 1 : А-Б / В. С. Сидоров. - Ростов н/Д : Гефест, 1994. - 512 с.

7. Донские казаки : крат. сб. рассказов из воен. жизни донцов, о их храбрости, находчивости в бою, 
преданности долгу и проч. / сост. и изд. А. Пивоваров. - Новочеркасск, 1892. - [6], 282, VIII с.

8. Картины былого Тихого Дона. В 2 т. Т. 1.М. : Граница, 1992. - 256 с.

9. Керсновский, А. А. История русской армии. В 4 т. Т. 1 : От Нарвы до Парижа 1700-1814 гг. / А. А. Керсновский. - М. : Голос, 1992. - 304 с.

10. Корягин, С. В. Иловайские / С. В. Корягин // Донская генеалогия и семейная история донского казачества. - Вып. 17. - М. : Русаки, 2001. - 120 с.

11. Корягин, С. В. Русско-турецкая война. 18061812. Период 1806-1809/ С. В. Корягин // Донская генеалогия и семейная история донского казачества. Вып. 113. - М. : Древлехранилище, 2014. -256 с.

12. Ланжерон, А. Ф. Записки графа Ланжерона. Война с Турцией 1806-1812 гг. / А. Ф. Ланжерон // Русская старина. - 1908. - Т. 134, кн. 4-6. Апрельиюнь. - С. 225-240, 661-969.

13. Ланжерон, А. Ф. Записки графа Ланжерона. Война с Турцией 1806-1812 гг. / А. Ф. Ланжерон // Русская старина. - 1909. - Т. 138, кн. 4-6. Апрельиюнь. - С. 535-590.

14. Ланжерон, А. Ф. Записки графа Ланжерона. Война с Турцией 1806-1812 гг. / А. Ф. Ланжерон // Русская старина. - 1909. - Т. 139, кн. 7-8. Июльавгуст. - С. 164-206.

15. Михайловский-Данилевский, А. И. Описание турецкой войны в царствование императора Александра, с 1806 до 1812 года. В 2 ч. Ч. 1 : с картою театра войны и 30-ю планами. - СПб. : Тип. Штаба Отд. корпуса внугр. стражи, 1843.- [4], VIII, 280 с., 14 л. карт., план.

16. На всегдашнюю память будущих времен. Письма атамана Платова к императрице Марии Федоровне // Источник. - 1993. - № 4. - С. 63-74.

17. Сапожников, А. И. Граф Матвей Иванович Платов. Опыт научной биографии : автореф. дис. ... канд. ист. наук : 07.00.02 / Сапожников Александр Иванович. - СПб., 1995. - 17 с.

18. Соловьев, С. М. История России с древнейших времен. В 15 кн. Кн. XV / С. М. Соловьев ; отв. ред. Л. В. Черепнин. - М. : Соцэкгиз, 1966. - 703 с.

\section{REFERENCES}

1. Anisimov E. General Bagration. Zhizn $i$ voyna [General Bagration. Life and War]. Moscow, Molodaya gvardiya Publ., 2009. 832 p.

2. Novitskiy V.F. et al., ed. Voennaya ehntsiklopediya: v 18 t. [Military Encyclopedia. In 18 Vols.]. Vol. 4: [B - Bomba]. Saint Petersburg, Tovarishcestvo Sytina, 1911, pp. 319-640.

3. Voskoboynikov S.G. Uchastie donskikh kazakov $v$ russko-turetskoy voyne 1806-1812 gg.: dis. ... kand. ist. nauk: 07.00.02 [Participation of the Don Cossacks in the Russian-Turkish War of
1806-1812. Cand. hist. sci. diss.]. Rostov-on-Don, 2006. $265 \mathrm{p}$.

4. Delo o razgrome turetskogo korpusa 4 sentyabrya 1809 g. pri ukreplenii Rassevato [The Case of the Defeat of the Turkish Corps September 4, 1809 Near the Fortress of Rassevato]. Gosudarstvennyy arkhiv Rostovskoy oblasti (GARO) [State Archive of Rostov Region], f. 46, inv. 1, d. 109. 391.

5. Denisov A.K. Zapiski donskogo atamana [Notes of the Don Ataman]. Saint Petersburg, WIRD, 1999. $256 \mathrm{p}$.

6. Donskaya kazachya ehntsiklopediya Vladimira Sidorova [Don Cossack Encyclopedia of Vladimir Sidorov]. Vol. 1: A-B. Rostov-on-Don, Gefest Publ., 1994. 512 p.

7. Donskie kazaki : krat. sb. rasskazov iz voen. zhizni dontsov, o ikh khrabrosti, nakhodchivosti v boyu, predannosti dolgu i proch. [Don Cossacks. A Short Collection of Stories from the Military Life of Donets, Their Courage, Resourcefulness in Battle, Devotion to Duty, and so On]. Novocherkassk, 1892. [6], 282, VIII p.

8. Kartiny bylogo Tikhogo Dona. V 2 t. T. 1 [Paintings of Former Quiet Flows the Don. In 2 Vols. Vol. 1]. Moscow, Granitsa Publ., 1992. 256 p.

9. Kersnovskij A.A. Istoriya russkoy armii. $V 4 t$. T. 1: Ot Narvy do Parizha 1700-1814 gg. [History of the Russian Army. In 4 Vols. Vol. 1. From Narva to Paris. 1700-1814]. Moscow, Golos Publ., 1992. 304 p.

10. Koryagin S.V. Ilovayskie. Donskaya genealogiya $i$ semeynaya istoriya donskogo kazachestva [Ilovaisky. Don Genealogy and Family History of the Don Cossacks]. Iss. 17. Moscow, Rusaki Publ., 2001. 120 p.

11. Koryagin S.V. Russko-turetskaya voyna. 1806-1812. Period 1806-1809 [Russian-Turkish War. 1806-1812. The Period 1806-1809]. Donskaya genealogiya i semeynaya istoriya donskogo kazachestva [Don Genealogy and Family History of the Don Cossacks]. Iss. 113. Moscow, Drevlekhranilishche Publ., 2014. 256 p.

12. Langeron A.F. Zapiski grafa Lanzherona. Voyna s Turtsiey 1806-1812 gg. [Notes of Count Langeron. The War with Turkey in 1806-1812]. Russkaya starina [Russian Antiquity], 1908, vol. 134, book 4-6. April-June, pp. 225-240, 661-696.

13. Langeron A.F. Zapiski grafa Lanzherona. Voyna s Turtsiey 1806-1812 gg. [Notes of Count Langeron. War with Turkey 1806-1812]. Russkaya starina [Russian Antiquity], 1909, vol. 138, book 4-6. April-June, pp. 535-590.

14. Langeron A.F. Zapiski grafa Lanzherona. Voyna s Turtsiey 1806-1812 gg. [Notes of Count Langeron. The War with Turkey in 1806-1812]. Russkaya starina [Russian Antiquity], 1909, vol. 139, book 7-8. July-August, pp. 164-206. 


\section{ИСТОРИЯ И КУЛЬТУРА НАРОДОВ ЮГА РОССИИ}

15. Mikhailovsky-Danilevsky A.I. Opisanie turetskoy voyny $v$ tsarstvovanie imperatora Aleksandra, s 1806 do 1812 goda. V 2 ch. Ch. 1: s kartoyu teatra voyny i 30-yu planami [Description of the Turkish War in the Reign of Emperor Alexander, from 1806 to 1812. In 2 Pts. Pt. 1: With a Map of the Theater of War and 30 Plans]. Saint Petersburg, Tipografiya Shtaba otdelnogo korpusa vnutrenney strazhi, 1843. [4], VIII, 280 p., 14 1. map, plan.

16. Na vsegdashnyuyu pamyat budushchikh vremen. Pisma atamana Platova k imperatritse Marii Fedorovne [For the Everlasting Memory of
Future Times. Letters of Ataman Platov to Empress Maria Fedorovna]. Istochnik [Source], 1993, no. 4, pp. 63-74.

17. Sapozhnikov A.I. Graf Matvey Ivanovich Platov. Opyt nauchnoy biografii: avtoref. dis. ... kand. ist. nauk: 07.00.02 [Count Matvei Ivanovich Platov. Experience in Scientific Biography. Cand. hist. sci. abs. diss.: 07.00.02]. Saint Petersburg, 1995.17 p.

18. Soloviev S.M. Istoriya Rossii s drevneyshikh vremen. $V 15 \mathrm{kn}$. Kn. $X V$ [History of Russia from the Earliest Times. In 15 Books. Book XV]. Moscow, Sotsekgiz, 1966. $703 \mathrm{p}$.

\section{Information About the Author}

Andrey V. Venkov, Doctor of Sciences (History), Professor, Head of the Laboratory of Cossacks, Federal Research Centre The Southern Scientific Centre of the Russian Academy of Sciences (SSC RAS), Chekhov St, 41, 344006 Rostov-on-Don, Russian Federation, andrey_venk@rambler.ru, https://orcid.org/0000-0002-4455-2822

\section{Информация об авторе}

Андрей Вадимович Венков, доктор исторических наук, профессор, заведующий лабораторией казачества, Федеральный исследовательский центр Южный научный центр РАН (ЮНЦ РАН), просп. Чехова, 41, 344006 г. Ростов-на-Дону, Российская Федерация, andrey_venk@rambler.ru, https://orcid.org/0000-0002-4455-2822 